\title{
Vegetation successions in response to Holocene climate changes in the central Tibetan Plateau
}

\author{
Quan $\mathrm{Li}^{\mathrm{a},{ }^{*}, \text { Houyuan Lu }}{ }^{\mathrm{b}}$, Caiming Shen ${ }^{\mathrm{c}, \mathrm{d}}$, Yan Zhao ${ }^{\mathrm{a}}$, Quansheng Ge ${ }^{\mathrm{a}}$ \\ ${ }^{a}$ Key Laboratory of Land Surface Pattern and Simulation, Institute of Geographical Sciences and Natural Resources Research, Chinese Academy of Sciences, \\ Beijing 100101, China \\ ${ }^{\mathrm{b}}$ Key Laboratory of Cenozoic Geology and Environment, Institute of Geology and Geophysics, Chinese Academy of Sciences, Beijing 100029, China \\ ${ }^{c}$ College of Tourism and Geographical Sciences, Yunnan Normal University, Kunming 650500, China \\ d Atmospheric Sciences Research Center, State University of New York, Albany, NY 12203, USA
}

\section{A R T I C L E I N F O}

\section{Article history:}

Received 5 January 2015

Received in revised form

1 July 2015

Accepted 18 July 2015

Available online 29 July 2015

\section{Keywords:}

Vegetation succession

Climate change

Pollen

Holocene

Central Tibetan Plateau

\begin{abstract}
A B S T R A C T
Alpine vegetation in the central Tibetan Plateau is vulnerable to climate change. Nine lacustrine pollen records with well-constrained chronologies and high-resolution data were reviewed to document regional and local patterns of alpine vegetation succession in this region, and to understand the climatic driving forces for these changes. According to the relationship between modern pollen distribution and climate condition in the central Tibetan Plateau, Cyperaceae is a moisture-favored and cold-resistant component in both the vegetation and pollen assemblages in the region, while Artemisia is a droughttolerant and temperate component. Within an east-west transect across contemporary alpine steppe zone and alpine meadow zone of the central Tibetan Plateau, Kobresia (Cyperaceae)-dominated alpine meadow expanded westwards to invade the alpine steppe (dominated by Artemisia and Poaceae), and to replace the Artemisia-rich temperate steppe on a regional scale during the mid-Holocene, probably driven by the enhanced precipitation. Vegetation within a south-north transect, covered by alpine steppe and temperate steppe, underwent a turnover in steppe composition from a predominance of Artemisia during the first half of the Holocene to a predominance of Cyperaceae in the latter half on a regional scale, caused by a decline in the temperature. Furthermore, altitudinal vegetation belts in the central Tibetan Plateau shifted downwards in response to cooling climate since the early Holocene. Therefore, monsoonal precipitation and insolation-driven temperature changes may be the key climate driving forces for the Holocene vegetation successions in the central Tibetan Plateau.
\end{abstract}

() 2015 Elsevier Ltd. All rights reserved.

\section{Introduction}

The central Tibetan Plateau (TP) covers the vast interior plateau at an average elevation of $4500-5200 \mathrm{~m}\left(27^{\circ} 23^{\prime}-33^{\circ} 30^{\prime} \mathrm{N}\right.$, $86^{\circ}-95^{\circ} \mathrm{E}$ ) to the south of the Kunlun Mountain and north of the Himalaya Mountains (Tibetan Investigation Group, 1966). The central TP is located close to the northern boundary of the modern Asian Summer Monsoon system (Ren et al., 1979; Chinese Academy of Sciences (1984); Yao et al., 2013), and is characterized by alpine vegetation types including alpine meadow, alpine steppe and temperate steppe (Hou, 2001). Vegetation changes in the region during the Holocene are attracting increasing attention due to the

\footnotetext{
* Corresponding author.

E-mail address: liquan@igsnrr.ac.cn (Q. Li).
}

sensitivity of alpine vegetation to climate change (Herzschuh et al., 2006; Shen et al., 2008) and human activity (Miehe et al., 2006). Among numerous paleoenvironmental proxies, lacustrine pollen records with continuous sedimentation and high resolution have become one of the major archives for paleovegetation and paleoclimate reconstructions in the region (Sun et al., 1993; Shen, 2003; Herzschuh et al., 2006; Tang et al., 2009; Li et al., 2011).

Palynological research has figured some patterns of vegetation change in the central TP, including: 1) Alpine meadow had expanded westwards at the expense of alpine steppe and temperate steppe since the mid-Holocene (Shen, 2003; Herzschuh et al., 2009). 2) Vegetation changed from Artemisia-rich steppe to Cyperaceae-dominated steppe in the mid-Holocene as documented by pollen spectra in Lake Zigetang (Herzschuh et al., 2006). 3) Marsh meadow developed around lake basins in the late Holocene (Sun et al., 1993; Gu et al., 1994). 4) Altitudinal vegetation belt 
shifted downward on the north slope of Nyainqentanglha Mountains since the mid-Holocene (Li et al., 2011).

However, questions remain open regarding the vegetation changes on different spatial scales, their different responses to changes in Holocene climate in terms of temperature and precipitation, and as well as the impacts from human activity. For example, precipitation changes may have played a major role in the westward shifts of alpine meadow in Co Ngion area (Shen et al., 2008), and in the vegetation change from temperate steppe to alpine meadow in Koucha area (Herzschuh et al., 2009). However, temperature is also assumed to be responsible for vegetation transition between alpine meadow and forest (Zhao et al., 2011). A few studies suggested that human activity is one reason for forest decline and meadow expansion in the central and southern TP in the early Holocene (e.g., Miehe et al., 2009), whereas other paleovegetation records showed no evidence of anthropogenic impacts on vegetation (Herzschuh et al., 2006, 2011).

Here, we introduce the relationship between climate condition and modern pollen distributions of major pollen taxa in the central $\mathrm{TP}$, and synthesize nine Holocene lacustrine pollen records with reconstructed paleovegetation and paleoclimate changes from an east-west transect and a south-north transect (Fig. 1). This review compiles pollen-based paleovegetation successions with independent records of monsoon intensity and climate changes to expand the understanding on the response of alpine vegetation to climate change, and to verify the hypotheses about climatic driving for vegetation successions in the central TP.

\section{Study region, data source, and analysis methods}

The modern climate of the central TP is characterized by a latitudinal gradient of temperature and a near-longitudinal gradient of monsoonal precipitation. The mean annual temperature (MAT) descends from 8 to $10{ }^{\circ} \mathrm{C}$ in the south to $-6 \sim 0{ }^{\circ} \mathrm{C}$ in the north. The mean annual precipitation (MAP) decreases from more than $600 \mathrm{~mm}$ in the east to 100 200 $\mathrm{mm}$ in the west (Hou, 2001; Lu et al., 2011). Vegetation in the central TP shows a distinct southeast-northwest gradient, from alpine meadow zone and temperate subalpine steppe zone, to alpine steppe zone (Fig. 1) (Hou, 2001; Editorial Committee of Vegetation Map of China (2007)).
1) Temperate subalpine steppe zone. In the central-southern TP (MAT of $0 \sim 3{ }^{\circ} \mathrm{C}$, MAP of $250 \sim 400 \mathrm{~mm}$ ), river valleys and lake basin areas below $4400 \mathrm{~m}$ are covered by temperate steppe dominated by Artemisia spp., Stipa bungeana, Aristida triseta and shrub of Sophora moorcroftiana. The areas above $4400 \sim 4600 \mathrm{~m}$ are occupied by grasses of Stipa purpurea, Artemisia wellbyi, A. younghusbandii, Orinus thoroldii, and shrubs like Caragana versicolor and Dasiphora parvifolia.

2) Alpine steppe zone. It occurs in the central-western TP at elevations of $4500 \sim 5100 \mathrm{~m}$ (MAT of $-6 \sim 0{ }^{\circ} \mathrm{C}$, MAP of $150 \sim 300 \mathrm{~mm}$ ). Alpine steppe in Changtang Plateau, northern region of central TP, is dominated by Poaceae (e.g. S. purpurea) and Artemisia spp., while in the western region it is dominated by S. purpurea, Carex moorcroftii and Ceratoides compacta.

3) Alpine meadow zone. This vegetation type occurs in the central-northeastern TP at elevations of $3300 \sim 4500 \mathrm{~m}$ (MAT of $-3 \sim 4{ }^{\circ} \mathrm{C}$, MAP of $350 \sim 700 \mathrm{~mm}$ ). It mainly consists of Kobresia pygmaea, and shrubs like Rhododendron spp., Salix spp., Dasiphora spp. and Sibiraea anngustata. The associated taxa include K. humilis, Stipa aliena, S. capillacea, S. purpurea, Festuca ovina, Polygonum spp., Carex spp., Thalictrum spp. and Potentilla anserina. Alpine meadow usually occurs as an altitudinal vegetation belt on mountain slopes with an upper elevation limit of $4700 \sim 5600 \mathrm{~m}$ and an elevation extent of 500 800 m, between alpine steppe belt and alpine sparse vegetation belt (Zhang et al., 1981; Miehe and Miehe, 2000).

There are many paleoclimate records from the central TP. However, there are large differences in their age-controls and temporal resolutions. This study examines five lacustrine fossil pollen records from Selin Co, Xuguo Co, Co Ngion, Ahung Co and Koucha Lake within an east-west transect across modern alpine meadow zone and alpine steppe zone, and the other four pollen records from lake Zigetang, Nam Co, Chen Co and Hidden Lake within a south-north transect across temperate subalpine steppe zone and alpine steppe zone in the region (Fig. 1, Table 1). Uncalibrated radiocarbon dates from the record of Selin Co were calibrated to calendar years before present (BP = before $1950 \mathrm{AD}$ ) by using Calib7.0.2 based on the IntCal13 dataset (Reimer et al., 2013). An age-depth model for this site was established by linear interpolation.

Published palynological climatic proxies cited here, including

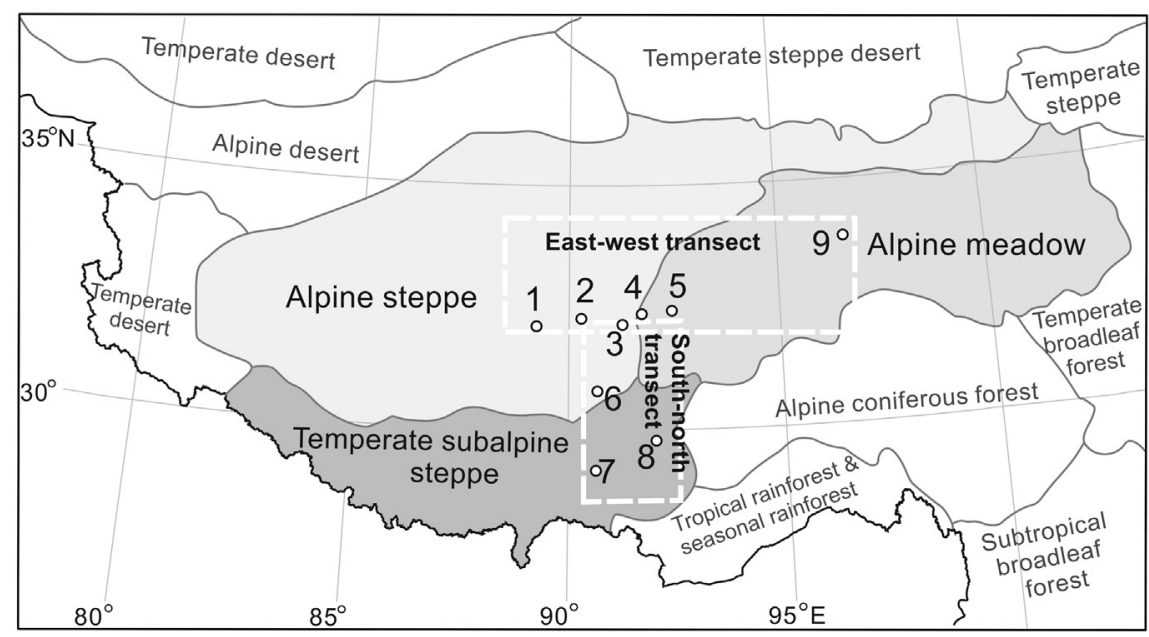

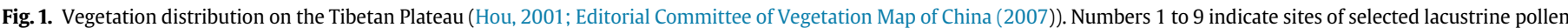

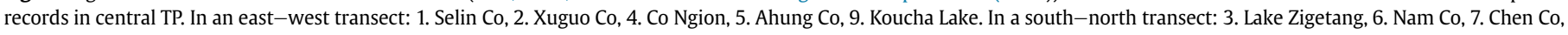
8 . Hidden Lake. See Table 1 for site information and references. 
Table 1

List of selected lacustrine fossil pollen records of the central TP.

\begin{tabular}{|c|c|c|c|c|c|c|}
\hline Code & Site name & Location $(\mathrm{N}, \mathrm{E})$ & Elevation ( $\mathrm{m}$ a.s.l.) & Palynological climate proxy ${ }^{\mathrm{a}}$ & No. of dates; time spans & Reference \\
\hline 1 & Selin Co & $31^{\circ} 34^{\prime}-57^{\prime}, 88^{\circ} 31^{\prime}-89^{\circ} 21^{\prime}$ & 4530 & Pollen concentration, Cyperaceae percentage & 5; last $13 \mathrm{ka}$ & Sun et al., 1993 \\
\hline 2 & Xuguo Co & $31^{\circ} 57^{\prime}, 90^{\circ} 20^{\prime}$ & 4595 & Poaceae/Artemisia ratio & 4 ; last $8.6 \mathrm{ka}$ & Shen, 2003 \\
\hline 3 & Lake Zigetang & $32^{\circ} 00^{\prime}, 90^{\circ} 54^{\prime}$ & 4560 & $\mathrm{~A} / \mathrm{Cy}$ ratio, $\mathrm{A} / \mathrm{C}$ ratio, pollen concentration & 5; last $10.8 \mathrm{ka}$ & Herzchuh et al., 2006 \\
\hline 4 & Co Ngion & $31^{\circ} 28^{\prime}, 91^{\circ} 30^{\prime}$ & 4515 & Pollen-based transfer functions & 12 ; last $6 \mathrm{ka}$ & Shen et al., 2008 \\
\hline 5 & Ahung Co & $31^{\circ} 37^{\prime}, 92^{\circ} 04^{\prime}$ & 4575 & Poaceae/Artemisia ratio & $59 ; 8-2$ ka BP & Shen, 2003 \\
\hline 6 & Nam Co & $30^{\circ} 40^{\prime}-31^{\circ} 00^{\prime}, 90^{\circ} 10^{\prime}-15^{\prime}$ & 4718 & $\mathrm{~A} / \mathrm{Cy}$ ratio & 12; last 8.4 ka & Li et al., 2011 \\
\hline 7 & Chen Co & $28^{\circ} 53^{\prime}-59^{\prime}, 90^{\circ} 33^{\prime}-39^{\prime}$ & 4420 & Pollen-based transfer functions & $17 ; 30-3$ ka BР & Lu et al., 2011 \\
\hline 8 & Hidden Lake & $29^{\circ} 49^{\prime}, 92^{\circ} 32^{\prime}$ & 4980 & Pollen-based transfer functions & 11 ; last $14.1 \mathrm{ka}$ & Shen, 2003 \\
\hline 9 & Koucha Lake & $34^{\circ} 00^{\prime}, 97^{\circ} 12^{\prime}$ & 4540 & Pollen-based transfer functions & 5; last $16.7 \mathrm{ka}$ & Herzschuh et al., 2009 \\
\hline
\end{tabular}

${ }^{\text {a }} \mathrm{A} / \mathrm{Cy}$ ratio: pollen concentration ratio of Artemisia to Cyperaceae; A/C ratio: pollen concentration ratio of Artemisia to Chenopodiaceae.

pollen concentration ratios of Artemisia/Cyperaceae (A/Cy), Artemisia/Chenopodiaceae $(\mathrm{A} / \mathrm{C}$ ) and Poaceae/Artemisia, and quantified paleoclimate changes of temperature and precipitation by transfer functions, were resampled at 200-year interval with the exception of Xuguo Co and Ahung Co which were resampled at 500-year interval. They were correlated with oxygen isotope records of ice cores in TP and monsoon records of the Indian Summer Monsoon domains, and then compared with paleovegetation changes including quantitative results of pollen-based biomization and discriminant analysis.

\section{Climatic implications of modern pollen distribution}

The relationships among modern pollen assemblages, vegetation distribution and climate are essential to vegetational and climatic interpretations of fossil pollen records (Prentice, 1985; Cour et al., 1999). Previous investigations of modern pollen assemblages have indicated that Artemisia and Cyperaceae are the most dominant taxa in the central TP (Yu et al., 2001; Shen et al., 2006; Lu et al., 2011).

Cyperaceae pollen occurs in high proportions $(>50 \%)$ in the alpine meadow zone (relatively cold and wet, MAT of $-3 \sim 4{ }^{\circ} \mathrm{C}$, MAP of 350 700 mm) (Fig. 2A; Lu et al., 2011), and in the alpine meadow belt on the mountain slopes of the central to eastern TP (Li et al., 2011). Pollen concentrations of Cyperaceae show a descending trend from east to west along with the descending MAP. In addition, modern Cyperaceae pollen percentages correlate negatively with mean July temperatures in the TP (Shen et al., 2006).

High proportions of Artemisia pollen (30 50\%) occur in the temperate subalpine steppe zone of the central to southern TP (relatively warm and dry, MAT of $0 \sim 3{ }^{\circ} \mathrm{C}$, MAP of $250 \sim 400 \mathrm{~mm}$ ) (Fig. 2B; Yu et al., 2001; Lu et al., 2011). In the central TP, percentages of Artemisia pollen show a descending trend from south to north along with the descending MAT (Fig. 2B).

Therefore, it can be inferred that Cyperaceae is a moisturefavored and cold-resistant component, and Artemisia is a drought-tolerant and temperate component in both the vegetation and pollen assemblages of the central TP (Herzschuh et al., 2011; Zhao et al., 2011). Consequently, Cyperaceae-dominated alpine meadow is vulnerable to changes in precipitation (effective moisture) (Shen, 2003; Shen et al., 2008), while Artemisia-dominated steppe is sensitive to changes in temperature in the region (Herzschuh et al., 2006; Li et al., 2011).

\section{Holocene vegetation changes inferred from pollen records in the central TP}

\subsection{Vegetation changes within an east-west transect}

Fossil pollen records at Selin Co, Xuguo Co, Co Ngion, Ahung Co and Koucha Lake (labeled as 1, 2, 4, 5 and 9 in Fig. 1) within the east-west transect have documented the regional and local vegetation changes of alpine meadow, alpine steppe and marsh meadow during the Holocene (Fig. 3).

Selin Co is located in the alpine steppe zone. The pollen assemblages before $12 \mathrm{ka}$ BP indicated sparse vegetation with very low pollen concentrations. During 12 7.5 ka BP, there was a rise in pollen concentrations and Artemisia, Ephedra and Poaceae, indicating Artemisia-Cyperaceae alpine steppe. During 7.5 1 ka BP, peaks of pollen concentration suggested dense steppe vegetation dominated by Artemisia and Cyperaceae. During the last millennium, a marked expansion of local sedge marsh on lake shores was reflected by a decrease in Artemisia pollen and an increase of Cyperaceae and Ranunculaceae (Sun et al., 1993, Fig. 3A), when the lake level fluctuated frequently with an overall pattern of decline (Gu et al., 1994). In the adjacent lakes of Ahung Co and Xuguo Co, results of pollen-based discriminant analysis also showed that Poaceae-Artemisia alpine steppe occupied the region before the late Holocene (8.5 4 ka BP), followed by an expansion of marsh meadow in lake basins after $4 \mathrm{ka}$ BP (Shen, 2003).

The fossil pollen record of Co Ngion documented several vegetation shifts of alpine meadow-steppe ecotone (MSE) on a regional scale (Shen, 2003). Results of vegetation discriminant analysis showed that during 6 4.9, 4.4 3.9, and 2.8 1.6 ka BP, alpine steppe occupied the region caused by eastward shifts of the MSE, whereas alpine meadow became dominant when the MSE shifted westwards during 4.9 4.4, 3.9 2.8, and after $1.6 \mathrm{ka}$ (Fig. 3B) (Shen et al., 2008).

Koucha Lake is situated in the alpine meadow zone, and surrounded by Kobresia meadows. Pollen-based biomization analysis showed that temperate steppe of Artemisia (pollen percentages of 27 51\%) prevailed during 12 6.6 ka BP. After 6.6 ka BP, Cyperaceaedominant alpine meadow (pollen percentage of $~ 50 \%$ ) colonized the region (Herzschuh et al., 2009).

According to pollen records in the east-west transect of the central TP, regional vegetation switched from an Artemisia-rich steppe to a Cyperaceae-dominated alpine meadow during the Holocene. The ecotone of alpine steppe and alpine meadow shifted back and forth along the longitude gradient since the midHolocene. Marsh meadow developed locally around lake basins in the late Holocene (Fig. 5A).

\subsection{Vegetation changes within a south-north transect}

The south-north transect is located at the transition between alpine steppe and temperate subalpine steppe zones in the central TP. Lacustrine pollen records from Lake Zigetang, Nam Co and Hidden Lake (labeled as 3, 6, and 8, respectively, in Fig. 1) have documented transitions of regional steppe vegetation and shifts of local altitudinal belts during the Holocene (Fig. 4).

Lake Zigetang is surrounded by alpine steppe of Poaceae (e.g., $S$. purpurea) and Cyperaceae (C. moorcroftii and Kobresia pygmea) on 


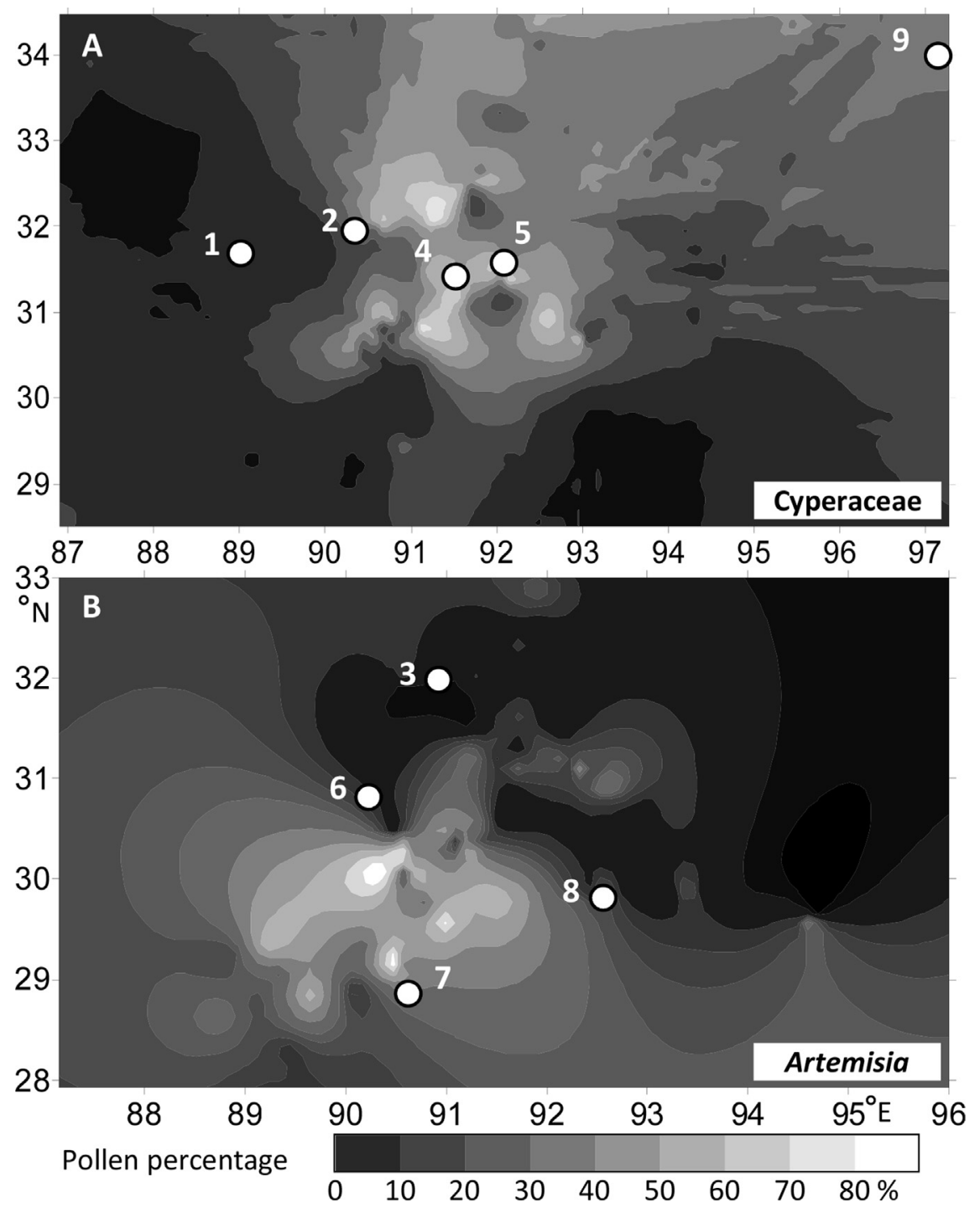

Fig. 2. Modern pollen distribution of Cyperaceae and Artemisia in the east-west and south-north transects of the central TP (based on published data from Lu et al., 2011).

lake plains, and by Kobresia alpine meadow on the distant slopes of the Tanggula Mountains (Wang and Herzschuh, 2011). Pollen record and biomization analysis have revealed a marked vegetation turnover from a temperate steppe of Artemisia and Poaceae to an alpine steppe of dominant Cyperaceae and Poaceae at $4.4 \mathrm{ka} B P$ (Fig. 4A) (Herzschuh et al., 2006).

Nam Co is located close to northern slopes of the Nyainqentanglha Mountains, which are covered by altitudinal vegetation belts of alpine steppe, alpine meadow and sparse vegetation along an elevation gradient (Zhang et al., 1981). According to modern pollen investigations in the lake drainage, pollen assemblages from the alpine steppe at lower elevations $(<4800 \mathrm{~m})$ contain high proportions of Artemisia (25.1\%) and Poaceae (11.5\%), while those from alpine meadow on the upper slopes (4800 5200 m) contain abundant Cyperaceae (63.1\%). Fossil pollen records and reconstructed paleovegetation by discriminant analysis suggested a general decline of the altitudinal vegetation belts. Alpine steppe of Artemisia (pollen percentages from 65\% to 39\%) and Poaceae retreated during the last $8.4 \mathrm{ka}$, while alpine meadow of Cyperaceae (from $15 \%$ to $43 \%$ ) shifted downwards to the lake shore (Fig. 4B) (Li et al., 2011). Local vegetation of alpine meadow around Hidden Lake were stabilized during the last $12 \mathrm{ka}$, with an exception of pine and birch forest occurrence during 8 6.6 ka BP resulted from the upward shift of altitudinal vegetation belts (Shen, 2003).

Paleovegetations within the south-north transect of central TP went through a steppe composition turnover from a dominance of Artemisia during the first half of Holocene to a priority of Cyperaceae in the latter half. Meanwhile, altitudinal vegetation belts shifted downwards in mountainous region (Fig. 5B).

\section{Alpine vegetation successions in response to Holocene climate changes in the central TP}

Vegetation succession in the central TP showed sensitive responses to Holocene climate change in terms of both precipitation (effective moisture) and temperature (Fig. 5).

The central TP has received moisture supply mainly from Indian Summer Monsoon (ISM) during the Holocene, according to observation on rainfall oxygen isotope (Yao et al., 2013) and numerous paleoclimate researches in the TP (e.g., Morrill et al., 2006; Bird et al., 2014; Günther et al., 2015). Multi-proxy paleomonsoon records from the ISM domains (Overpeck et al., 1996; Fleitmann et al., 2003; Gupta et al., 2003) and the TP (e.g., independent monsoon or 

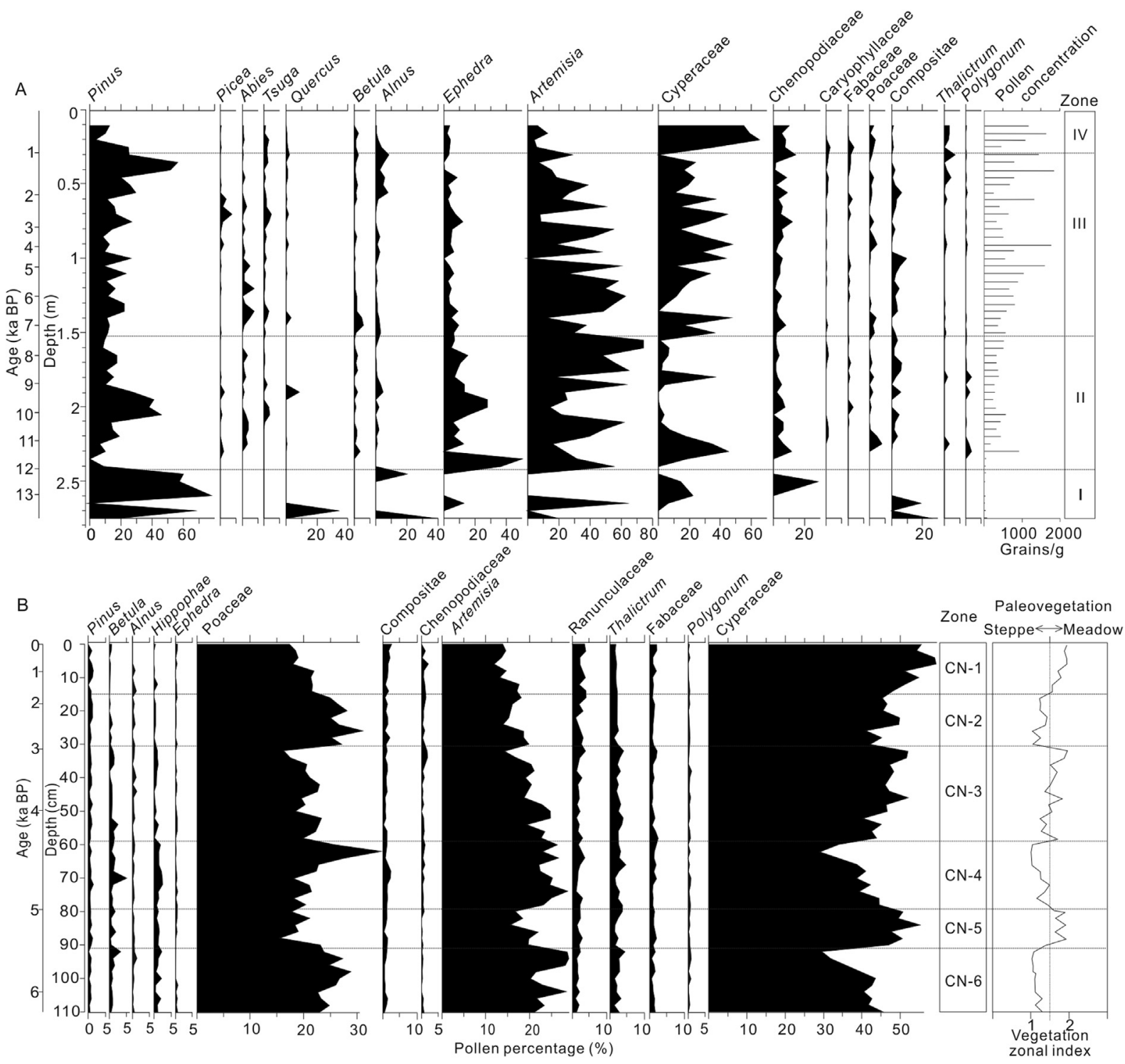

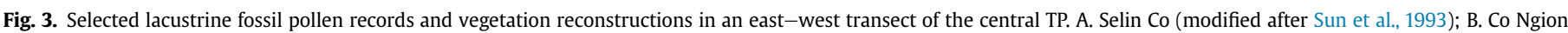
(Shen et al., 2008)

precipitation proxies from Hong et al., 2003; and Günther et al., 2015) suggested that ISM and monsoonal precipitation remain maximum intensity during the early to mid-Holocene, and gradually weaken after mid-Holocene, and then slightly intensified in the late Holocene (Fig. 5A).

The long-term trend of steppe-meadow vegetation successions in the central TP during the Holocene covared with those of past monsoon variations of the ISM, although dating uncertainty exists among different records, highlighting that monsoon-derived precipitation is the dominant driving force of vegetation changes between alpine steppe and alpine meadow in the region (Fig. 5A). Regional vegetation of the eastern TP changed from Artemisia-rich (drought-tolerant) steppe to Cyperaceae-dominated (moisturefavored) alpine meadow at around $6.6 \mathrm{ka} \mathrm{BP}$, in correspondence with strong ISM and relatively high effective moisture condition in the mid-Holocene (Koucha Lake, Herzschuh et al., 2009). Meanwhile, the ecotones of alpine meado0077-steppe in the central TP shifted eastward with expansion of drought-tolerant Artemisia alpine steppe during the intervals of weak ISM, whereas during the strong ISM intervals, it shifted westward and the alpine steppe was replaced by Cyperaceae meadow (Co Ngion, Shen et al., 2008). Correspondingly, quantitative results of precipitation by the pollenbased transfer functions reached as high as $>550 \mathrm{~mm}$ (Chen Co and Hidden Lake), and $>400 \mathrm{~mm}$ (Koucha Lake) during the early to midHolocene, and then decreased to $<400 \mathrm{~mm}$ in the central TP (Fig. 5A).

Holocene temperature variations in the TP showed an overall pattern of gradual decrease from the early and mid-Holocene to the late Holocene (e.g., Thompson et al., 1997, 2006; Morrill et al., 2006; Zhao et al., 2013), which is attributed to the declining solar insolation during the same period (Berger and Loutre, 1991) (Fig. 5B).

In the central TP, insolation-driven temperature is an important climate variable that is driving changes in vegetation succession between temperate steppe and alpine steppe, and shifts of altitudinal vegetation belt (Shen, 2003; Herzschuh et al., 2006; Li et al., 2011) (Fig. 5B). Numerous paleoclimate records have revealed a warm climate during the early and mid-Holocene, and a relatively cold climate in the late Holocene in the region (e.g., Morrill et al., 2006; Thompson et al., 2006; Wu et al., 2006; Zhu et al., 2008). Correspondently, regional vegetation transited from Artemisia-rich 

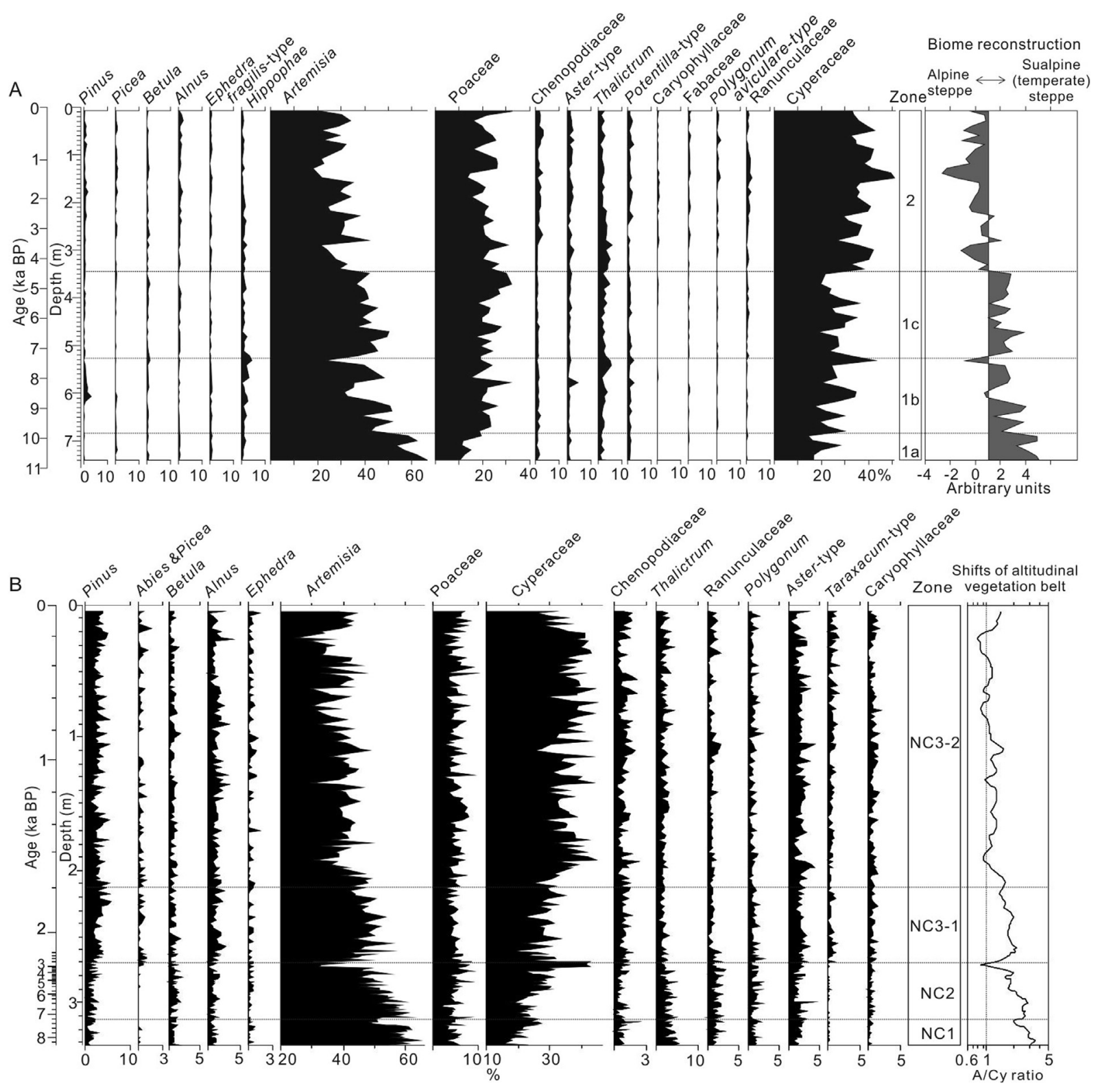

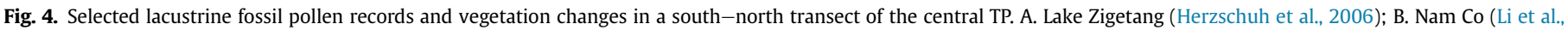
2011).

temperate steppe to Cyperaceae-dominated (cold-resistant) alpine steppe (Herzschuh et al., 2006), and local altitudinal vegetation belt gradually moved downwards during the Holocene in the central TP (Li et al., 2011). Furthermore, pollen-based quantitative reconstructions of past temperature yielded a marked drop by $1 \sim 3{ }^{\circ} \mathrm{C}$ (MAT and mean July temperature $\mathrm{T}_{\text {July }}$ ) from the early to midHolocene (Koucha Lake, Herzschuh et al., 2009; Chen Co, Lu et al., 2011), and a decrease by about $1 \sim 2{ }^{\circ} \mathrm{C}\left(\mathrm{T}_{\text {July }}\right)$ from the mid-to Late Holocene in the region (Hidden Lake, Shen, 2003; Co Ngion, Shen et al., 2008).

Some previous studies in the central and southern TP suggest that anthropogenic impacts such as pasturage could be responsible for the decline in forest and the expansion of meadow since the early Holocene (Miehe et al., 2006, 2009). However, most of the palynological research in this region shows no evidence of human disturbance to alpine vegetation during the Holocene (Herzschuh et al., 2006, 2011; Li et al., 2011). In addition to the lack of archaeological evidence, it is difficult to differentiate between natural-zoogenic and anthropo-zoogenic grazing from the pollen records, which makes it problematic to evaluate the influence of human activity on vegetation cover (Miehe et al., 2009; Herzschuh et al., 2011). Therefore, anthropogenic influence on changes in Holocene vegetation in the central TP requires further investigation on modern pollen assemblages under deforestation and grazing, and macro- and micro-botanical evidence including fossil pollen records.

\section{Conclusions}

Fossil pollen records in the central TP have documented vegetation successions in response to climate change in the Holocene. Based on correlations between modern pollen distributions and climate, it is inferred that Cyperaceae is a moisture-favored and cold-resistant component, and that Artemisia is a drought-tolerant 
A

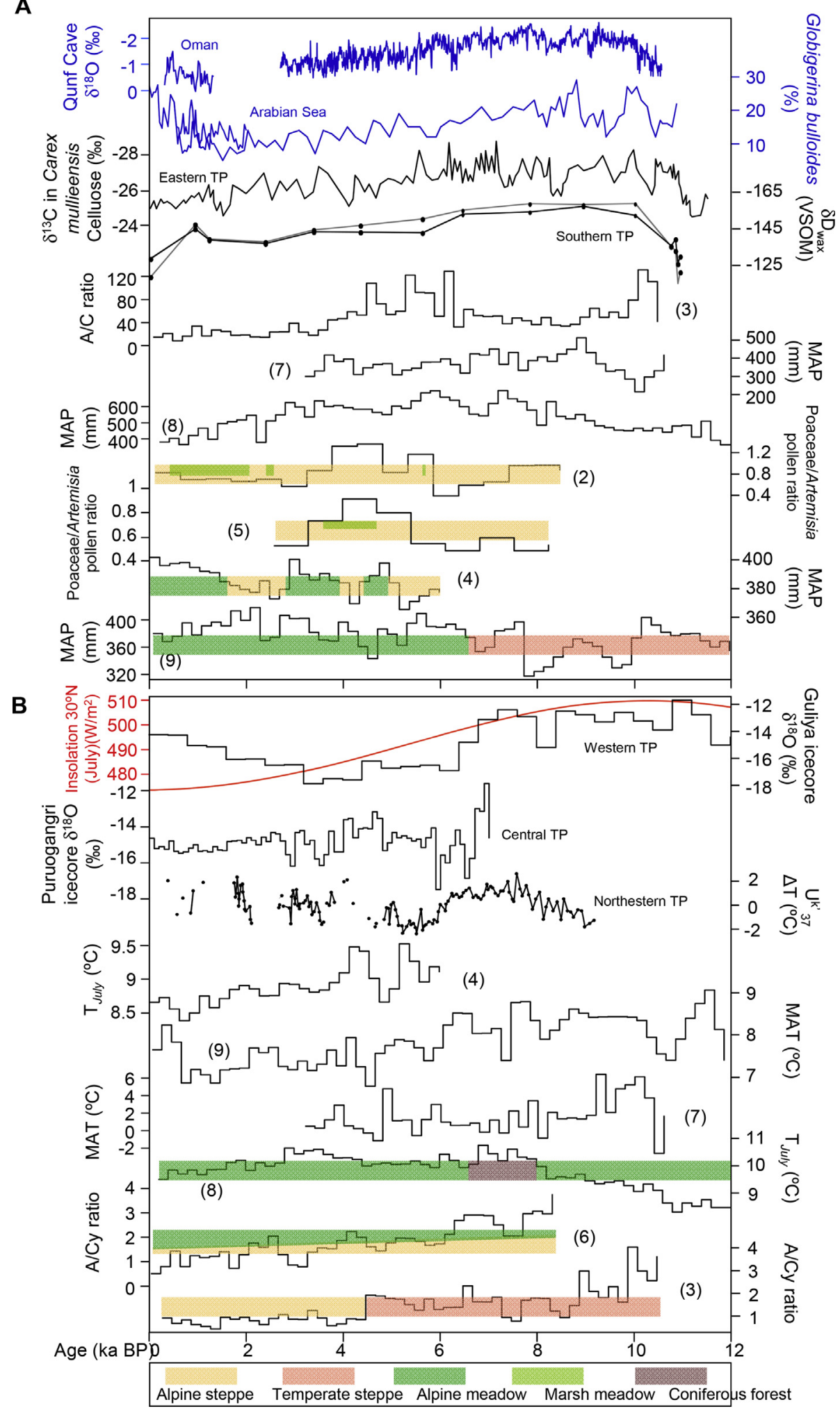

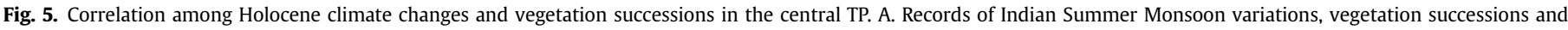

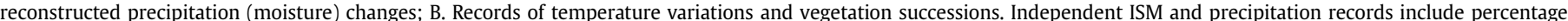

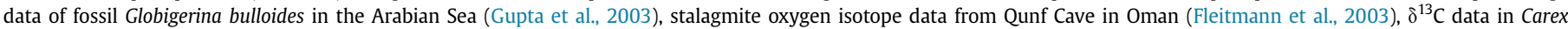

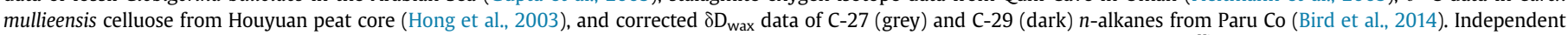

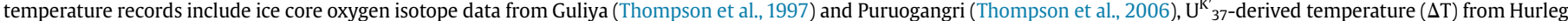

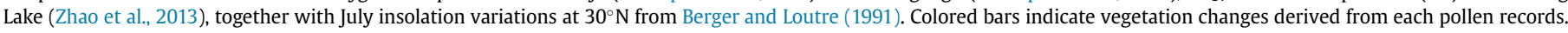
See Table 1 for site information and references. 
and temperate component in both vegetation and pollen assemblages in this region. Lacustrine pollen records from an east-west transect across the central TP show that Cyperaceae-dominated alpine meadow expanded to invade Artemisia-rich alpine steppe and temperate steppe in response to relatively abundant monsoonal precipitation during the mid-to late Holocene. Within a south-north transect, predominance element of regional steppe vegetation changed from Artemisia during the first half of the Holocene to Cyperaceae in the latter half, and altitudinal vegetation belts on the mountain regions shifted downwards in elevation during the Holocene in response to the reduced temperatures. This synthesis on changes in Holocene vegetation and climate suggest that variations of monsoonal precipitation and 8insolation-driven temperature are the predominant driving forces for changes in alpine vegetation in the central TP.

In the past two decades, palynological studies on lacustrine sediments have drawn a sketch of Holocene paleovegetation successions in response to climate changes in the central TP, and provided some valuable quantitative climatic records. However, there are still some uncertainties and challenges.

1) There are few paleovegetation study in the northern TP, limiting our knowledge about the vegetation response to climate change and glacier fluctuation in the transition zone of alpine steppe and alpine desert.

2) Modern pollen investigations on natural and artificial vegetation, farmland, and pasturing areas under different grazing intensity in the future could set up some benchmarks for the detection of signal of ancient human activity imbedded in fossil pollen sequences.

3) There is still a lack of validation among quantitative paleoclimate records from different sources. More attentions should be paid to multi-proxy researches on biomarkers, hydrogen and oxygen isotopes, as well as fossil pollen. These proxies could provide past temperature and precipitation variations separately, and be crosscheck and validated with each other.

\section{Acknowledgments}

Authors thank the editor and two anonymous reviewers. We would like to thank Dr. Linda Perry, Prof. Zhu Liping, Dr. Wang Junbo and Dr. Qin Feng for helpful discussions and language corrections. This work was supported by the National Natural Science Foundation of China (grant numbers 41471169, 41102221, 41330105 and 41271226), and the Open Research Fund of Key Laboratory of Tibetan Environmental Changes and Land Surface Processes, Chinese Academy of Sciences (TEL 201205).

\section{References}

Berger, A., Loutre, M.F., 1991. Insolation values for the climate of the last 10 million years. Quat. Sci. Rev. 10, 297-317.

Bird, B.W., Polisar, P.J., Lei, Y.B., Thompson, L.G., Yao, T.D., Finney, B.P., Bain, D.J., Pompeani, D.P., Steinman, B.A., 2014. A Tibetan lake sediment record of Holocene Indian summer monsoon variability. Earth Planet. Sci. Lett. 399, 92-102.

Chinese Academy of Sciences (Compilatory Commission of Physical Geography of China), 1984. Physical Geography of China: Climate. Science Press, Beijing (in Chinese).

Cour, P., Zheng, Z., Duzer, D., Calleja, M., Yao, Z., 1999. Vegetational and climatic significance of modern pollen rain in northwestern Tibet. Rev. Palaeobot. Palynol. 104, 183-204.

Editorial Committee of Vegetation Map of China, Chinese Academy of Sciences, 2007. Vegetation Map of the People's Republic of China(1:1000000). Geological Press, Beijing.

Fleitmann, D., Burns, S.J., Mudelsee, M., Neff, U., Kramers, J., Mangini, A., Matter, A. 2003. Holocene forcing of the Indian monsoon recorded in a stalagmite from southern Oman. Science 300, 1737-1739.

Gu, Z.Y., Liu, J.Q., Yuan, B.Y., Liu, D.S., Zhang, G.Y., 1994. Lacustrine authigenic deposition expressive of environment and the sediment record from Siling Co,
Xizang (Tibet), China. Quat. Sci. 2, 162-174 (in Chinese).

Günther, F., Witt, R., Schouten, S., Mäusbacher, R., Daut, G., Zhu, L.P., Xu, B.Q. Yao, T.D., Gleixner, G., 2015. Quaternary ecological responses and impacts of the Indian ocean summer monsoon at Nam Co, southern tibetan plateau. Quat. Sci. Rev. 112, 66-77.

Gupta, A.K., Anderson, D.M., Overpeck, J.T., 2003. Abrupt changes in the Asian southwest monsoon during the Holocene and their links to the North Atlantic Ocean. Nature 421, 354-357.

Herzschuh, U., 2006. Palaeo-moisture evolution in monsoonal central Asia during the last 50000 years. Quat. Sci. Rev. 25, 163-178.

Herzschuh, U., Kramer, A., Mischke, S., Zhang, C.J., 2009. Quantitative climate and vegetation trends since the late glacial on the northeastern Tibetan Plateau deduced from Koucha Lake pollen spectra. Quat. Res. 71, 162-171.

Herzschuh, U., Ni, J., Birks, H.J.B., Böhner, J., 2011. Driving forces of mid-Holocene vegetation shifts on the upper Tibetan Plateau, with emphasis on changes in atmospheric $\mathrm{CO}_{2}$ concentrations. Quat. Sci. Rev. 30, 1907-1917.

Herzschuh, U., Winter, K., Wünnemann, B., Li, S., 2006. A general cooling trend on the central Tibetan Plateau throughout the Holocene recorded by the Lake Zigetang pollen spectra. Quat. Int. 154-155, 113-121.

Hong, Y.T., Hong, B., Lin, Q.H., Zhu, Y.X., Shibata, Y., Hirota, M., Uchida, M., Leng, X.T. Jiang, H.B., Xu, H., Wang, H., Yi, L., 2003. Correlation between indian ocean summer monsoon and North Atlantic climate during the holocene. Earth Planet. Sci. Lett. 211, 371-380.

Hou, X., 2001. Vegetation Atlas of China. Science Press, Beijing (in Chinese).

Li, Q., Lu, H.Y., Zhu, L.P., Wu, N.Q., Wang, J.B., Lu, X.M., 2011. Pollen-inferred climate changes and vertical shifts of alpine vegetation belts on the northern slope of the Nyainqentanglha mountains (central Tibetan Plateau) since $8.4 \mathrm{kyr}$ BP. Holocene 21, 939-950.

Lu, H.Y., Wu, N.Q., Liu, K.B., Zhu, L.P., Yang, X.D., Yao, T.D., Wang, L., Li, Q., Liu, X.Q., Shen, C.M., Li, X.Q., Tong, G.B., Jiang, H., 2011. Modern pollen distributions in Qinghai Tibetan Plateau and the development of transfer functions for reconstructing Holocene environmental changes. Quat. Sci. Rev. 30, 947-966.

Miehe, G., Miehe, S., 2000. Environmental changes in the pastures of Xizang. Marbg. Geogr. Schriften 135, 282-312.

Miehe, G., Miehe, S., Kaiser, K., Reudenbach, C., Behrendes, L., Duo, L., Schlütz, F., 2009. How old is pastoralism in Tibet? an ecological approach to the making of a Tibetan landscape. Palaeogeogr. Palaeoclimatol. Palaeoecol. 276, 130-147.

Miehe, G., Miehe, S., Schlütz, F., Kaiser, K., Duo, L., 2006. Palaeoecological and experimental evidence of former forests and woodlands in the treeless desert pastures of Southern Tibet (Lhasa, A.R. Xizang, China). Palaeogeogr. Palaeoclimatol. Palaeoecol. 242, 54-67.

Morrill, C., Overpeck, J.T., Cole, J.E., Liu, K.B., Shen, C.M., Tang, L.Y., 2006. Holocene variations in the Asian monsoon inferred from the geochemistry of lake sediments in central Tibet. Ouat. Res, 65, 232-243.

Overpeck, J.T., Anderson, D., Trumbore, S., Prell, W., 1996. The southwest Indian monsoon over the last 18,000 years. Clim. Dyn. 12, 213-225.

Prentice, I.C., 1985. Pollen representation, source area and basin size: towards a unified theory of pollen analysis. Quat. Res. 23, 76-86.

Reimer, P.J., Bard, E., Bayliss, A., Beck, J.W., Blackwell, P.G., Bronk Ramsey, C., Buck, C.E., Cheng, H., Edwards, R.L., Friedrich, M., Grootes, P.M., Guilderson, T.P., Haflidason, H., Hajdas, I., Hatté, C., Heaton, T.J., Hogg, A.G., Hughen, K.A., Kaiser, K.F., Kromer, B., Manning, S.W., Niu, M., Reimer, R.W., Richards, D.A., Scott, E.M., Southon, J.R., Turney, C.S.M., van der Plicht, J., 2013. IntCal13 and MARINE13 radiocarbon age calibration curves 0-50000 years cal BP. Radiocarbon 55 (4), 1869-1887.

Ren, M.E., Yang, R.Z., Bao, H.S., 1979. Elements of the Physical Geography of China. Commercial Press, Beijing (in Chinese).

Shen, C.M., 2003. Millennial-scale Variations and Centennial Scale Events in the Southwest Asian Monsoon: Pollen Evidence from Tibet. Ph.D. dissertation. Louisiana State University, Baton Rouge.

Shen, C.M., Liu, K.B., Morrill, C., Overpeck, J.T., Peng, J.L., Tang, L.Y., 2008. Ecotone shift and major droughts during the mid-late Holocene in the central Tibetan Plateau. Ecology 89, 1079-1088.

Shen, C.M., Liu, K.B., Tang, L.Y., Overpeck, J.T., 2006. Quantitative relationships between modern pollen rain and climate in the Tibetan Plateau. Rev. Palaeobot. Palynol. 140, 61-77.

Sun, X.J., Du, N.Q., Chen, Y.S., Gu, Z.Y., Liu, J.Q., Yuan, B.Y., 1993. Holocene palynological records in Lake Selincuo, northern Xizang (Tibet). Acta Bot. Sin. 35, 943-950 (in Chinese).

Tang, L.Y., Shen, C.M., Li, C.H., Peng, J.L., Liu, H., Liu, K.B., Morrill, C., Overpeck, J.T., Julia, E.C., Yang, B., 2009. Pollen inferred vegetation and environment changes in central Tibetan Plateau since 8200 year BP. Sci. China Ser. D Earth Sci. 52, 1104-1114.

Thompson, L.G., Yao, T.D., Davis, M.E., Henderson, K.A., Mosley-Thompson, E., Lin, P.N., Beer, J., Synal, H.A., Cole-Dai, J., Bolzan, J.F., 1997. Tropical climate Instability: the last glacial cycle from a Qinghai-Tibetan ice core. Science 276, $1821-1825$.

Thompson, L.G., Yao, T.D., Davis, M.E., Mosley-Thompson, E., Mashiotta, T.A., Lin, P.N., Mikhalenko, V.N., Zagorodnov, V.S., 2006. Holocene climate variability archived in the puruogangri ice cap on the central Tibetan Plateau. Ann. Glaciol. 43, 61-69.

Tibetan Investigation Group, 1966. Vegetation in the Central Tibet. Science Press, Beijing (in Chinese).

Wang, Y.B., Herzschuh, U., 2011. Reassessment of Holocene vegetation change on the upper Tibetan Plateau using the pollen-based reveals model. Rev. Palaeobot. 
Palynol. 168, 31-40.

Wu, Y. Lücke, A., Jin, Z., Wang, S., Schleser, G.H., Battarbee, R.W., Xia, W. 2006. Holocene climate development on the central Tibetan Plateau: a sedimentary record from Cuoe Lake. Palaeogeogr. Palaeoclimatol. Palaeoecol. 234, 328-340. Yao, T.D., Masson-Delmotte, V., Gao, J., Yu, W.S., Yang, X.X., Risi, C., Sturm, C., Werner, M., Zhao, H.B., He, Y., Ren, W., Tian, L.D., Shi, C.M., Hou, S.G., 2013. A review of climatic controls on $\delta^{18} \mathrm{O}$ in precipitation over the Tibetan Plateau: observations and simulations. Rev. Geophys. 51, 525-548.

Yu, G., Tang, L.Y., Yang, X.D., Ke, X.K., Harrison, S.P., 2001. Modern pollen samples from alpine vegetation on the Tibetan Plateau. Glob. Ecol. Biogeogr. 10, 503-519.

Zhang, J.W., Wang, J.T., Chen, W.L., Li, B.S., 1981. On latitudinal zoning of vegetation in the Qinghai Xizang (Tibet) Plateau. Sci. Sin. 24, 1154-1165.

Zhao, C., Liu, Z.H., Rohling, EJ., Yu, Z.C., Liu, W.G., He, Y.X., Zhao, Y., Chen, F.H., 2013. Holocene temperature fluctuations in the northern Tibetan Plateau. Quat. Res. $80,55-65$.

Zhao, Y., Yu, Z.C., Wan, W.W., 2011. Holocene vegetation and climate histories in the eastern Tibetan Plateau: controls by insolation-driven temperature or monsoon-derived precipitation changes? Quat. Sci. Rev. 30, 1173-1184.

Zhu, L., Wu, Y., Wang, J., Lin, X., Ju, J., Xie, M., Li, M., Mäusbacher, R., Schwalb, A. Daut, G. 2008. Environmental changes since 8.4 ka reflected in the lacustrine core sediments from Nam Co, central Tibetan Plateau, China. Holocene 18 831-839. 